\title{
Gambaran Kadar Kolesterol pada Akseptor Kontrasepsi Suntik
}

\section{Overview of Cholesterol Levels in Injection Contraception Acceptors}

\author{
PUPUNG CAHYA WULANDARI \\ SURATI
}

\author{
Jurusan Analis Kesehatan Poltekkes Kemenkes Semarang \\ Jl. Wolter Monginsidi Pedurungan Tengah Semarang \\ Email:pupungcahya7@gmail.com
}

\begin{abstract}
Abstrak
Berdasarkan data hasil sensus penduduk yang tercatat 2016 lebih dari 258 juta jiwa dan diproyeksikan bahwa jumlah ini akan terus bertambah. Program keluarga berencana untuk perencanaan jumlah keluarga dan pembatasan dengan peggunaan alat kontrasepsi. Jumlah Pasangan Usia Subur (PUS) Provinsi Jawa Tengah tahun 2016 sebanyak 6.727.894 dari seluruh PUS sebesar $78.6 \%$ peserta KB aktif. Kontrasepsi yang paling banyak digunakan kontrasepsi suntik 3 bulan (DMPA). Di Kota Semarang, Kecamatan Pedurungan jumlah PUS paling banyak. Kelurahan yang paling banyak akseptor kontrasepsi suntik adalah Kelurahan Telogosari Kulon. Kontrasepsi suntik menyebabkan perubahan metabolisme lemak melalui perubahan kadar kolesterol adanya pengaruh hormon progesteron. Rancangan penelitian yang digunakan adalah penelitian jenis deskriptif dengan pendekatan cross-sectional. Sampel penelitian sebanyak 25 akseptor kontrasepsi suntik 3 bulan. Hasil penelitian menunjukkan rata-rata kadar kolesterol $209.5 \mathrm{mg} / \mathrm{dl}$, sebanyak 12 akseptor kotrasepsi suntik memiliki kadar kolesterol normal (48\%) dan 13 akseptor memiliki kadar kolesterol diatas normal (52\%). Kontrasepsi suntik 3 bulan dapat meningkatkan kadar kolesterol.
\end{abstract}

Kata Kunci: Kadar kolesterol ; Akseptor DMPA

\begin{abstract}
Based on the population census data from 2016, there are more than 258 million people and it's projected will continue grow. Family planning programs for family planning total and restriction on the use of contraceptive. The number of fertile age couple in the province of central java in 2016 was 6.727 .894 of all fertile age couples of 78.6\% active family planning participants. The type of contraception that is often used is injection at $54.2 \%$. The most many used contraceptive injection is contraceptive injection 3 month (DMPA). In Semarang City, Pedurungan district the most number of fertile age couples. The village with the most injectable contraceptive acceptors is Tlogosari Kulon Village. Injectable contraception causes changes in fat metabolism through changes in cholesterol levels. Descriptive type research with cross sectional. The study sample was 25 injectable contraceptive acceptors 3 months. The result examination of cholesterol levels in injectable cholesterol levels in injectable contraceptive acceptors 3 months on average cholesterol levels is $209.5 \mathrm{mg} / \mathrm{dl}$, as many 12 acceptor contraceptive injective 3 months had normal cholesterol levels (48\%), and as many 13 acceptor contraceptive injective 3 months had above normal cholesterol levels (52\%). 3 month injection contraception can increase cholesterol levels.
\end{abstract}

Keyword: Cholesterol levels ; DMPA acceptors 


\section{Pendahuluan}

Indonesia merupakan negara berkembang yang tidak luput dengan masalah kependudukan. Berdasarkan data hasil sensus penduduk yang tercatat 2016 lebih dari 258 juta jiwa dan diproyeksikan bahwa jumlah ini akan terus bertambah (BPS, 2017). Oleh karena itu pemerintah melakukan upaya untuk meningkatkan derajat kesehatan masyarakat. Dalam kehidupan modern setiap pasangan membutuhkan perencanaan yang matang untuk mencapai kesejahteraan keluarga yang optimal. Progran yang menyediakan kontrasepsi moder yang didukung oleh kebijakan pemerintah merupakan program yang paling efektif (Depkes RI, 2007).

Keluarga berencana adalah suatu upaya yang berguna untuk perencanaan jumlah keluarga dengan pembatasan yang bisa dilakukan dengan penggunaan alat-alat kontrasepsi seperti kondom, IUD, dan sebagainya. ( Dinkes Jateng, 2016).

Jumlah kontrasepsi yang paling diminati saat ini adalah kontrasepsi dengan metode suntik (BKKBN, 2018), sedangkan jenis kontrasepsi suntik yang paling sering digunakan adalah depo progestin yang berisi DMPA (Depo Medroxyl Progesteron Asetat) dengan masa efektif 12 minggu dan cyclofem atau cyclo provera yang berisi kombinasi esterogen dan progestero dengan masa efektif 4 minggu (Saifuddin, Abdul Bari, 2006).

Kontrasepsi suntikan menyebabkan perubahan metabolism lemak melalui perubahan kadar HDL dan LDL. HDL bersifat antiatherogenik, sebaiknya kadar LDL dan trigliserida yang tinggi menyebabkan penyakit kardiovaskuler di perifer dan arteria koronaria yang menyebabkan penyakit kardiovaskuler. Penggunaan kontrasepsi hormonal jangka panjang menyebabkan peningkatan LDL, sedangkan HDL bervariasi (Djaswadi, 2008).

Menurut Hartanto (2004) dalam Dewi, Ayu Devita Citra (2018) penambahan berat badan bervariasi antara kurang $1 \mathrm{~kg}$ sampai $5 \mathrm{~kg}$ dalam tauhn pertama, kenaikan rata-rata untuk setiap tahun bervariasi antara kurangdari $1 \mathrm{~kg}$ sampai $5 \mathrm{~kg}$ tahun pertama.

Perubahan kenaikan berat badan ini dapat dipengaruhi oleh berbagai faktor hormonal yang terkandung dalam kontrasepsi suntik DMPAA yaitu hormon progesteron. Progesteron yang akan mempermudah perubahan karbohidrat dan gula menjadi lemak, sehingga lemak subkutan bertambah. Faktor lain yang berperan penting dalam mempengaruhi berat badan adalah faktor genetik, faktor lingkungan, faktor psikis, faktor obat-obatan dan aktifitas fisik (Hartanto, 2010; Irianto, 2014; Prawirohardjo, 2014 dalam Prihati Dwi R).

Berdasarkan latar belakang yang telah diuraikan diatas, peneliti ingin mengetahui gambaran kadar kolesterol pada akseptor kontrasepsi suntik.

\section{Metode}

Penelitian ini merupakan penelitian observasional dengan pendekatan Cross Sectional yang bertujuan untuk mengetahui gambaran kadar kolesterol pada akseptor pada kontrasepsi suntik. Sampel yang digunakan dalam penelitian ini berupa darah vena dari 25 akseptor kontrasepsi suntik 3 bulan dengan jangka pemakaian lebih $\geq 3$ tahun. Peralatan yang digunakan berupa spuit, tourniquet, tabung vacutainer merah (tanpa antikoagulan), centrifuge dan Photometer Genius WP21B. Data pada penelitian ini merupakan data primer yaitu gambaran kadar kolesterol pada akseptor kontrasepsi suntik yang diperoleh dari pemeriksaan menggunakan Photometer Genius WP21B. Data yang diperoleh kemudian diolah dengan uji statistika secara deskriptif. Data diuji menggunakan aplikasi komputer Microsoft Excel 2013 dan SPSS 16.0 yang digunakan untuk menghitung nilai rata-rata, nilai median, nilai modus, nilai minimum dan nilai maksimal.

\section{Hasil dan Pembahasan}

Penelitian ini dilaksanakan pada tanggal 2-6 Februari 2019 dan 15 April 2019 di Puskesmas Tlogosari Kulon. Data diperoleh dari hasil pemeriksaan kadar kolesterol dengan spesimen darah tanpa antikoagulan (serum). Sampel penelitian yang digunakan sejumlah 25 
akseptor kontrasepsi suntik 3 bulan yang bersedia menjadi responden dalam penelitian ini. Sebelum pengambilan sampel darah dilakukan wawancara dengan kuisioner kepada responden mengenai usia, lama penggunaan, aktifitas fisik, asupan makanan dan obesitas. setelah diberi informed consent yang bersedia terdapat 25 akseptor kontrasepsi suntik 3 bulan. Kemudian dilakukan pemeriksaan kadar kolesterol menggunakan alat Photometer Genius WP 21B.

Data yang diperoleh menunjukkan bahwa rata-rata kadar kolesterol adalah 209.5 mg/dL. Kadar kolesterol tertinggi pada kode sampel A12 yaitu $363.5 \mathrm{mg} / \mathrm{dL}$ dan kadar kolesterol terendah pada kode sampel A14 yaitu 139,3 g/dL. Hasi rata-rata kadar kolesterol masih diatas rentang normal. Pemeriksaan menggunakn alat Photometer Genius WP 21B. Nilai normal kadar kolesterol $\leq 200 \mathrm{mg} / \mathrm{dL}$ menurut Permenkes 1792/MENKES/SK/XII/2010 tentang pedoman pemeriksaan kimia klinik. Pemeriksaan kadar kolesterol darah pada penellitian ini menggunakan reagen Diasys. Nilai rujukan Diasys kolesterol adalah $\leq 200$ $\mathrm{mg} / \mathrm{dL}$. Berdasarkan hal tersebut nilai rujukan yang dipakai adalah $\leq 200 \mathrm{mg} / \mathrm{dL}$ sesuai reagen yang digunakan saat penelitian.

Tabel 1 Distribusi frekuensi respoden berdasarkan kadar Kolesterol pada Akseptor Kontrasepsi Suntik 3 yang Tercatat di Puskesmas Tlogosari Kulon

\begin{tabular}{ccc}
\hline Kadar Kolesterol & Frekuensi & Presentase (\%) \\
\hline$<200 \mathrm{mg} / \mathrm{dl}$ & 12 & 48 \\
$\geq 200 \mathrm{mg} / \mathrm{dl}$ & 13 & 52 \\
\hline Total & 25 & 100
\end{tabular}

a. Usia

Wanita yang berusia 30-40 tahun merupakan usia yang dikatakan produktif karena belum menopause. Pada usia terebut para wanita menggunakan alat kotrasepsi untuk menguragi angka kelahiran. Hormon yang terdapat pada kontrasepsi suntik berupa hormon progestin akan merendahkan kadar HDL kolesterol namun mengakibatkan tigginya kadar LDL kolesterol sehingga menambah besarnya aterosklerosis (Hartanto, 2010).

\section{b. Lama Penggunaan}

Menurut hasil penelitian Tobing dalam W, Ngesti, Tutik Herawati dan Lenni Saragih (2015)

Tabel 2 Tabulasi silang lama penggunaan kontrasepsi suntik 3 bulan yang Tercatat di Puskesmas Tlogosari Kulon

\begin{tabular}{cccc}
\hline \multirow{2}{*}{$\begin{array}{c}\text { Lama penggunaan } \\
\text { kontrasepsi }\end{array}$} & Normal $(\%)$ & Diatas Normal (\%) & Total (\%) \\
\cline { 2 - 3 } & & & \\
\hline $3-6$ tahun & $12(48 \%)$ & $6(28 \%)$ & $19(76 \%)$ \\
$\geq 6$ tahun & $0(0 \%)$ & $13(52 \%)$ & $6(24 \%)$ \\
\hline Total $(\%)$ & $12(48 \%)$ & $25(100 \%)$ \\
\hline
\end{tabular}

Berdasarkan tabel 2 menunjukkan bahwa semakin lama penggunaan kontrasepsi suntik 3 bulan adanya kecenderungan kadar kolesterol di atas normal. Penggunaan kontrasepsi suntik 3 bulan dengan jangka 3-6 tahun sebagian besar 12 reponden (48\%) memiliki kadar kolesterol normal dan 7 responden (28\%) memiliki kadar kolesterol di atas normal. Sedangkan lama penggunaan kontrasepsi dengan jangka pemakaian $\geq 6$ tahun sebanyak 6 responden $(24 \%)$ memiliki kadar kolesterol di atas normal. 


\section{c. Perubahan Berat Badan}

Menurut data sekunder yang diperoleh melalui kuisioner. Perubahan berat badan ditinjau dari kartu kontrol $\mathrm{KB}$ dan saat dilakukan penellitian, sehingga peneiti mengkategorikan lama bekerja menjadi beberapa kelompok untuk memudahkan dalam mendeskripsikan.

Tabel 3 Pengkategorian Perubahan Berat Badan Akseptor Kontrasepsi Suntik 3 bulan dengan Kadar Kolesterol yang Tercatat di Puskesmas Tlogosari Kulon

\begin{tabular}{|c|c|c|c|}
\hline \multirow[b]{2}{*}{ Perubahan BB } & \multicolumn{2}{|c|}{ Kadar Kolesterol } & \multirow[b]{2}{*}{ Total (\%) } \\
\hline & Normal (\%) & Diatas Normal (\%) & \\
\hline Naik & $6(24 \%)$ & $12(48 \%)$ & $18(72 \%)$ \\
\hline Tetap & $5(20 \%)$ & $1(4 \%)$ & $6(24 \%)$ \\
\hline Turun & $1(4 \%)$ & $0(0 \%)$ & $1(4 \%)$ \\
\hline Total (\%) & $12(48 \%)$ & $13(52 \%)$ & $25(100 \%)$ \\
\hline
\end{tabular}

Berdasarkan tabel 3 menunjukkan bahawa adanya kecenderungan kenaikan berat badan sebanyak 18 responden (72\%) dari 25 responden. Sebagian kecil tidak mengalami perubahan berat badan sebanyak 6 respoden (24\%) dan sebanyak 1 responden (4\%) mengalami penurunan berat badan.

d. IMT

Tabel 4 Pengkategorian IMT Pada Akseptor Kontrasepsi Suntik 3 Bulan dengan Kadar Kolesterol yang Tercatat di Puskesmas Tlogosari Kulon

\begin{tabular}{cccc}
\hline & \multicolumn{2}{c}{ Kadar Kolesterol } & \\
\cline { 2 - 3 } IMT & Normal (\%) & Diatas Normal(\%) & Total (\%) \\
& $3(12 \%)$ & $1(4 \%)$ & $4(16 \%)$ \\
Normal & $8(32 \%)$ & $6(24 \%)$ & $14(56 \%)$ \\
Gemuk & $1(4 \%)$ & $6(24 \%)$ & $7(28 \%)$ \\
Obesitas & $12(48 \%)$ & $13(52 \%)$ & $25(100 \%)$ \\
\hline Total (\%) & & & \\
\hline
\end{tabular}

Berdasarkan tabel 4 menunjukkan bahwa sebagian besar responden penelitian mengalami kegemukan sebanyak 14 responden (56\%) dan sebagian kecil mengalami obesitas sebanyak 7 responden $(28 \%)$.

Nilai rujukan kadar kolesterol darah adalah $\leq 200 \mathrm{mg} / \mathrm{dl}$ menurut Permenkes 1792/MENKES/SK/XII/2010 tentang pedoman pemeriksaan kimia klinik. Berdasarkan hal tersebut nilai rujukan yang dipakai adalah $\leq 200 \mathrm{mg} / \mathrm{dl}$ sesuai reagen yang digunakan saat penelitian.

Kadar kolesterol setiap individu berbeda karena banyak faktor yang mempengaruhi seperti intake makanan tinggi lemak, gaya hidup dan aktifitas fisik. Kelebihan kolesterol akibat sering mengonsumsi makanan yag tinggi kolesterol dan kurangnya aktifitas fisik bisa menyebabkan gangguan pada sistem trasportasi baik secara langsung maupun tidak langsung (Magdalena,2015). Dari sekian responden penelitian berdasarkan data hasil kuisioner rata-rata responden penelitian mengonsumsi makanan berlemak dalam satu minggu. Gaya hidup sehat untuk menjaga kadar koelsterol dengan konsumsi makanan berserat dan olahraga secara teratur (Mamat, 2010).

Hasil kuisioner dan wawancara akseptor kontrasepsi suntik 3 bulan dan akseptor kontrasespi IUD. Kadar kolesterol pada kelompok akseptor kontrasepsi 
suntik 3 bulan sebanyak 12 responden penelitian (48\%) memiliki kadar kolesterol normal dan sebanyak 13 responden penelitian (52\%) memiliki kadar kolesterol diatas normal. Pada kontrasepsi suntik 3 bulan mengandung hormon progesteron. Hormon tersebut memiliki efek pada metabolisme lemak menyebabkan gangguan keseimbangan fraksi lemak darah (naik turunnya kadar HDL, LDL dan kolesterol total) karena adanya pengaruh hormonal yang terkandung dalam kontrasepsi (Sari, 2013). Kadar kolesterol pada kelompok akseptor kontrasepsi IUD sebanyak 10 responden penelitian (100\%) memiliki kadar kolesterol normal. Hal ini karena kontrasepsi IUD tidak mengandung hormonal (Affandi, Biran., George Adriaansz, Eko Rusdianto Gunardi. \& Harni Koesno, 2014).

Jangka lama menggunakan kontrasepsi suntik 3 bulan dan penggunaan kontrasepsi suntik secara teratur. Semakin sering seseorang mendapatkan suntik DMPA, maka akumulasi dan pengaruh hormone terhadap metabolisme lemak juga akan meningkat (Tobing dalam W, ngesti, Tutik Herawati dan Lenni Saragih, 2015). Hal ini juga sejalan dengan penelitian Didien Ika Setyarini (2013) tentang hubungan lama penggunaan DMPA semakin lama persentase akseptor yang memiliki kadar lemak dalam interval $30-35 \%$ dan $>35 \%$ dalam kategori mendekati tinggi dan tinggi. Hal ini disebabkan oleh hormon progesteron saja yang menyebabkan kadar esterogen menjadi berkurang.

Akseptor kontrasepsi suntik 3 bulan mengetahui efek samping dari kontrasepsi tersebut. Alat kontrasepsi memiliki efek samping, namun setiap individu tidak selalu akan mengalami efek samping yang ditimbulkan. Hal tersebut karena masing-masing individu memiliki adaptasi tersendiri terhadap pemberian hormon progesteron. Efek samping itu dianggap wajar oleh akseptor kontrasepsi suntik dan rasa nyaman menggunakan kontrasepsi sunntik 3 bulan karena dianggap praktis dan efektif (Didien Ika Setyarini, 2013).

Hormon progesteron yang terkandung dalam kontrasepsi suntik 3 bulan akan mempermudah perubahan karbohidrat dan gula menjadi lemak sehingga lemak subkutan bertambah (Hartanto, 2010; Irianto, 2014; Prawirohardjo, 2014). Sehingga akseptor terbiasa dengan sarapan pagi dan konsumsi makanan sehari 2-3 kali karena adanya faktor hormonal yang terkandung dalam kontrasepsi suntik 3 bulan.

Akseptor yang menjadi responden penelitian memiliki kebiasaan sarapan makanan tinggi lemak dan kolesterol akan meningkatkan kadar kolesterol total dan LDL (dalam Alodiea Yoentafara dan Santi Martini, 2017). Pola makan tersebut menyebabkan kenaikan berat badan pada akseptor kontrasepsi suntik 3 bulan. Estimasi peningkatan berat badan akseptor kontrasepsi suntik 3 bulan berdasarkan data hasil kuisioner 1-10 kg.

Akseptor melakukan diet untuk menurunkan berat badan dengan melakukan aktifitas fisik. Aktifitas fisik yang dilakukan dengan instensitas sedang dan secara teratur terjadi proses degradasi lemak. Berdasarkan hasil penelitian yang dilakukan oleh Raul (2009) bahwa tingkat aktivitas memiliki hubungan yang bermakna terhadap penurunan kadar kolesterol total dan peningkatan kolesterol HDL. Orang-orang yang melakukan olahraga secara teratur ditemukan peningkatan kadar HDL, penurunan LDL dan trigliserida (dalam Mamat, 2010).

Faktor-faktor yang dapat mempengaruhi kolesterol diantaranya usia, lama penggunaan, aktifitas fisik, asupan makanan dan obesitas. Usia responden penelitian dengan rentang 30-40 tahun yang merupakan usia produktif karena belum mengalami menopause. Pada rentang usia ini para akseptor kontrasepsi untuk mengurangi angka kelahiran. Hasil penelitian Tobing dalam W, Ngesti, Tutik Herawati dan Lenni Saragih (2015) semakin sering seseorang mendapatkan suntikan DMPA, maka akumulasi dan pengaruh hormon terhadap metabolisme lemak dalam tubuh juga akan meningkat. Aktivitas fisik yang dilakukan secara teratur sangat penting, selain untuk menghindari kegemukan, juga dapat menolong 
mencegah terjadinya penyakit akibat pola hidup seperti diabetes, serangan jantung dan stroke. Pada waktu melakukan aktivitas fisik otot-otot akan banyak memakai lebih banyak glukosa dari pada waktu melakukan aktivitas fisik. Obesitas mengakibatkan terjadinya perubahan lipid darah, yaitu peninggian kadar kolesterol darah, kadar LDL-kolesterol meningkat (kolesterol jahat, yaitu zat yang mempercepat penimbunan kolesterol pada dinding pembuluh darah), penurunan kadar HDL-kolesterol (kolesterol baik, yaitu zat yang mencegah terjadinya penimbunan kolesterol pada dinding pembuluh darah) (Mamat, 2010).

\section{Simpulan dan Saran}

\section{Simpulan}

Kadar kolesterol pada kelompok akseptor kontrasepsi suntik 3 bulan dengan rata-rata $209.5 \mathrm{mg} / \mathrm{dl}$ dengan nilai rujukan $\leq 200 \mathrm{mg} / \mathrm{dl}$. Nilai maksimum kadar kolesterol sebesar $363.5 \mathrm{mg} / \mathrm{dl}$ dan nilai minimum kadar kolesterol sebesar $139.3 \mathrm{mg} / \mathrm{dl}$.

Kadar kolesterol pada kelompok akseptor kontrasepsi suntik 3 bulan sebanyak 48\% sampel memiliki kadar kolesterol normal, sebanyak 52\% sampel memiliki kadar kolesterol diatas normal.

\section{Saran}

Peneliti selanjutnya, dapat dilakukan penelitian dengan mengukur kadar profil lipid yang lainnya (HDL-kolesterol, LDL-kolesterol, dan trigliserid).

Akseptor kontrasepsi yang obesitas disarankan untuk menjaga pola makan dan gaya hidup agar efek yang ditimbulkan akibat penggunaan kontrasepsi suntik 3 bulan tidak mengganggu kesehatan tubuh.

\section{Daftar Pustaka}

Affandi, Biran., George Adriaansz, Eko Rusdianto Gunardi dan Harni Koesno. 2014. Buku Panduan Praktis Pelayanan Kontrasepsi. Edisi 3, Cet 2. Jakarta: PT Bina Pustaka Sarwono Prawirohardjo.

Departemen Kesehatan Republik Indonesia. 2007.

Hartanto. 2004. dalam Dewi, Ayu Devita Citra. 2018. Gambaran Efek Samping KB Suntik Depo Medroksi Progesteron Asetat Pada Akseptor di Bidan Praktik Mandiri (BPM) Wilayah Kerja Kelurahan Sako Palembang Tahun 2017. STIK Bina Husada Palembang.

Hartanto. 2010. ; Irianto. 2014. ; Prawirohardjo. 2014. dalam Prihati, Dwi Retna. 2018. Pengaruh Kontrasepsi Suntik DMPA terhadap Kenaikan Berat Badan Tikus Betina Galur Wistar. Kementrian Kesehatan Politeknik Kesehatan Surakarta.

Hartanto. 2010. Keluarga Berencana dan Kontrasepsi. Jakarta : Sinar Harapan.

Magdalena. 2015. Hubungan asupan serat, kolesterol, natrium dan olahraga dengan kadar kolesterol dan hipertensi pada lansia. Jurusan Gizi Poltekkes Kemenkes Banjarmasin

Mamat. 2010. Faktor-faktor yang berhubungan dengan kadar Kolesterol HDL di Indonesia. Fakultas Kesehatan Masyarakat UI.

Profil Kesehatan Provinsi Jawa Tengah. 2016.

Saifuddin, Abdul Bari. 2006. Buku Ilmu Kebidanan Sarwono Prawirohardjo. Jakarta: Yayasan Bina Pustaka Sarwono Prawirohardjo.

Setyarini. 2013. dalam Prihati, Dwi Retna. 2018. Pengaruh Kontrasepsi Suntik DMPA Terhadap Kenaikan Berat Badan Tikus Betina Galur Wistar. Kementrian Kesehatan Politeknik Kesehatan Surakarta.

Setyarini, Didien Eka. 2013. Lama penggunaan Depo Medroksi Progesteron Asetat (DMPA) dan Indeks Massa Tubuh (IMT) Akseptor Kontrasepsi Suntik. Poltekkes Kemenkes Malang. 
Tobing dalam W, Ngesti., Herawati, Tutik., dan Lenni Saragih. 2015. Lama Pemakaian Alat Kontrasepsi Hormonal Suntik DMPA dan Gangguan Kardiovaskuler. Poltekkes Kemenkes Malang.

Yoeantafara, Aloediea dan Santi Martini. 2017. Pengaruh Pola Makan Terhadap Kadar Kolesterol Total. Fakultas Kesehatan Masyarakat Universitas Airlangga. 